\title{
Perdagangan Dan Mistisisme Dalam Islamisasi Di Sumatera Dan Jawa
}

\section{Masyhudi}

Keywords: diffusion, culture, religion, distribution, history, islam

\section{How to Cite:}

Masyhudi, nfn. (2003). Perdagangan Dan Mistisisme Dalam Islamisasi Di Sumatera Dan Jawa. Berkala Arkeologi, 23(2), 70-86. https://doi.org/10.30883/jba.v23i2.877

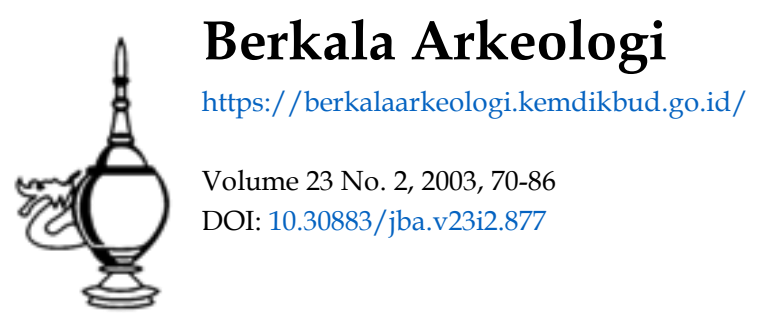




\title{
PERDAGANGAN DAN MISTISISME \\ DALAM ISLAMISASI DI SUMATERA DAN JAWA
}

\author{
Masyhudi
}

$\mathbf{P}$ endahuluan

Suatu pandangan bahwa perdagangan merupakan faktor yang dominan dalam proses masuknya Islam di Nusantara. Aktivitas tersebut meskipun telah berlangsung sejak sebelum Islam ada, tetapi justru dengan peran para pedagang dengan minat dan semangat yang tinggi untuk mengembangkan agama baru yang dianggapnya dapat memberikan kepuasan batin, terutama dalam rangka menuju kebahagiaan. Maka pada akhimya dengan minat dan semangat yang tinggi tersebut Islam dapat berkembang ke berbagi pelosok dunia.

Dalam Proses tumbuh dan berkembangnya Islam,tidak akan terlepas dari strategi dakwah yang dilakukan oleh para tokoh penyebar Islam, mulai dari mendirikan masjid, mengadopsi kesenian lokal menjadi kesenian yang bermuatan Islam, mendidik kader ulama, dakwah langsung kepada para penguasa dan keluarganya atau pendekatan langsung kepada masyarakat. Strategi ini dapat dilakukan melalui perdagangan, perkawinan, diskusi ataupun pendalaman tentang keagamaan Islam, serta dilakukan sesuai dengan tuntutan suasana, artinya memasukkan ajaran-ajaran Islam kepada masyarakat dengan memperhatikan kondisi sosial-budaya yang ada, sehingga kehadiran Islam dapat diterima dengan baik, tanpa adanya perlawana ataupun konflik. (Ambary, 1998 ).

Sementara itu sinkretisme yang kental dan pengaruh ajaran mistik dari Persia pada saat itu telah mewujudkan corak Islam Asia Tenggara berbeda dengan yang diajarkan oleh nabi Muhammad saw. Disamping itu juga perkembangan ajaran Islam yang semakin terpecah-pecah ke dalam sekte-sekte juga ikut mempengaruhi formasi masyarakat Islam di Indonesia karena hal tersebut juga berpengaruh pada corak birokrasi dan penerapan hukum Islam.

Diantara pendapat yang menonjol dikalangan para ahli tentang Islamisasi, bahwa Islamisasi telah dibawa oleh para pedagang dan guru tarekat melalui kota-kota pantai di Indonesia. Namun siapa yang menjadi aktor di antara mereka masih menjadi pertanyaan yang selalu menarik untuk didiskusikan. Hal demikian juga terjadi di Sumatera dan Jawa, yaitu mengenai berlangsungnya Islam masuk di beberapa daerah pantai di Sumatera dan Jawa. Tetapi persoalan kemudian, dalam konteks basis dan sosiokultural, apakah islamisasi tersebut berlangsung, siapakah aktor-aktor utamanya, apa dampak yang muncul dan sejauh mana respon Islam terhadap unsur-unsur yang telah ada ? Oleh karena itu dalam tulisan ini akan diuraikan tentang perkembangan 
Islam dengan setrategi perdagangan dan beberapa aliran mistisisme yang telah mewarnai perkembangan Islam di Sumatera dan Jawa.

$\mathbf{P}$ erdagangan Sebelum dan Sesudah Hadirnya Islam.

Mitologi tentang Raja Sulaiman, 1000 tahun sebelum Nabi Isa, a.s, mengenai pulau Ophir yang menghasilkan emas tampaknya menjadi salah satu pencetus gagasan untuk memperluas perdagangan ke Selatan dan Timur bagi orang Eropa dan Timur Tengah. Mitologi Ophir di mata pedagang menjadi semacam peta yang dibayangkan yang membangkitkan fantasi ekspansionis ke wilayah Timur yang dianggap kaya dengan emas. Dan pada saat itu pula Mesir telah menjadi arena perdagangan pada masa lampau yang menghubungkan antara Eropa, Timur Tengah, India, Cina, dan Asia Tenggara.

Hubungan dagang antara orang Eropa dengan Timur Tengah merupakan gambaran yang telah mewarnai peta dagang sebelum masa-masa Islam. Kenyataan ini menunjukkan bahwa hubungan dagang antara Eropa dengan Asia telah berlangsung semenjak sebelum nabi Isa a.s. Namun setelah terjadi perang salib antara Islam dan Kristen di Kawasan Utara, Barat tampaknya tidak lagi menguntungkan bagi kehidupan dagang, kondisi itu ternyata membuat serta mendorong para pedagang Islam di Timur Tengah untuk melakukan ekspansi dagangnya ke Timur dan Selatan.

Salah seorang pemikir yang telah mampu menggambarkan peta yang memasukkan pulau Sumatera kedalam peta yang dimanfaatkan untuk perdagangan Mesir, adalah Ptolomaeus, suami Cleopatra. Masuknya Sumatera ke dalam petanya terutama karena dari Sumatera utara itulah orang-orang Mesir mendapatkan kapur barus dari Barus yang digunakan untuk memufikasi jenazah. Disamping itu kebutuhan Mesir akan kemenyan juga di dapat di Sumatera.

Dalam pembuatan peta ia diilhami oleh kitab Ramayana dari India yang menggambarkan Sumatera (Swarnadwipa). Atas dasar itulah ia membuat buku berjudul Geographike Uplehesis dan menunjuk ke semenanjung Asia Tenggara sebagai pulau emas yang diimpikan semenjak mitos Ophir pada masa Sulaiman (Said, 1961).

Pada masa pra Islam di Asia Tenggara tampak bahwa Cinalah yang mendominasi perdagangan di kawasan Asia Tengah, Selatan dan Tenggara. Komodditi yang dimonopoli oleh Cina tersebut kemudian dibawa ke Timur Tengah, terutama Mesir dijadikan sebagai pasar andalan Eropa, sebelum ditemukan terusan Suez dan ditemukannya Tanjung Harapan oleh Portugis.

Kemudian setelah runtuhnya dominasi India dan Cina , karena ditaklukkannya India bagian utara yang kemudian merembet ke Selatan dan penyerangan ke Cina oleh 
tentara Islam di Timur Tengah, maka tampaklah gelombang orang-orang Arab mulai membentuk koloni-koloni bagi para pedagang. Hubungan dagang dan politik antara Cina dengan Persia, Cina dengan Sriwijaya, India dengan Sriwijaya dan India dengan Cina merupakan hubungan yang telah berlangsung selama berabad-abad. Hubungan semacam ini tidak mungkin terhapus begitu saja. Oleh karena itu ketika ajaran Muhammad (Islam) mulai mapan di Timur Tengah dan berkuasa di India bagiaan utara, maka arus perdagangan internasional semakin diintensifkan, demikian pula ajaran Islam itu sendiri.

Masyarakat Islam Timur Tengah yang telah merambah ke-Asia tampaknya dengan memanfaatkan jalur perdagangan Internasional ke India dan Asia Tenggara semakin menuju ke jalan ekspansionisme. Hal ini merupakan kekhawatiran bangsa Islam atas kekuatan Eropa yang semakin besar. Sehingga penaklukan India menjadi kunci utama untuk semakin menuju ke Nusantara. Pada masa itulah India menjadi tempat penting dalam rangka Islamisasi di kawasan Nusantara dan gelombang dalam melakukan ekspansinya telah membawa bekal sistem perpajakan, khususnya dalam perdagangan, pajak pelabuhan dan berbagai tata hukum Islam yang pada perkembangan kemudian menjadi suatu upaya birokratisasi yang mengiringi jalannya hegemonisasi melalui perdagangan dan penyebaran agama.

Di dalam perdagangan dan penerapan hukum Islam itulah proses monoterisasi dengan uang emas (Dinar) dan uang perak (Dirham) mewarnai pola ekonomi daerah-daerah koloni Islam. Sementara itu jalur perdagangan antara Timur Tengah, India, Cina, Asia Tengah dan Asia Tenggara menjadi suatu jalur yang kompleks dan semakin terintegrasi pada perdagangan laut yang global. Jalur perdagangan laut ini merupakan perdagangan metal (yang utama), kapas, sutera, dan rempah-rempah.

Masuknya Islam ke India merupakan gelombang ekspansionisme kesultanan yang berbendera Islam dalam rangka Hegemonisasi yang kemudia untuk mengukuhkan posisi ekonomi suatu kesultanan. Kemenangan Islam di India mencapai sukses pada masa Muhammad Ghuri yang mampu menaklukkan raja Delhi (Payne, 1987).

Penaklukan di India pada akhir abad ke-7 diikuti oleh pemapanan kerajaan Islam di India. Disamping itu berlangsungnya ekonomi kerajaan tetap menggunakan jalur perdagangan tradisional yang telah dipelopori oleh pedagang pra-Islam. Jalur yang merupakan basis ekonomi kerajaan pra-Islam yang diteruskan oleh kerajaan Islam penakluk telah mengindikasikan bahwa gelombang Islam telah masuk ke Nusantara semenjak India ditaklukkan. Akan tetapi meskipun Islam telah merambah ke Nusantara pada abad ke-7, pengaruh Islam di Nusantara pada waktu itu belum begitu berarti. Islamisasi belum berlangsung secara intensif karena masih kuatnya dominasi Cina dan India, bahkan Hinduisme dan Budhisme menjadi instrumen agama yang mengatur tata kehidupan masyarakat yang memiliki hubungan plitik dengan India dan Cina. 
Pada fase kemudian kekuatan Islam mulai mendapatkan angin untuk mendominasi perdagangan di Asia, organisasi internal di setiap koloni tersebut melengkapi dirinya dengan unsur kemiliteran untuk menjaga serangan dari perompak. Kemudian dalam perkembangan berikutnya, Sultan Delhi menjadi penguasa di seluruh kerajaan India. Islamisasi yang berlangsung melalui penaklukan untuk kepentingan dagang pun semakin meluas di seluruh India. Apabila Islam di Sumatera Utara dipengeruhi oleh pedagang dari Gujarat pada tahun $1229 \mathrm{M}$, maka corak masuknya Islam di Gujarat mejadi penting. Para pedagang Gujarat yang memanfaatkan Islam telah menjadi pengekspor batu nisan yang digunakan oleh para penguasa Islam di Sumetera Utara dan Jawa. Batu nisan dari Cambay tampak telah menjadi Simbol yang prestisius bagi sultan-sultan yang meninggal dan juga untuk melegitimasikan kerajaan tersebut di dalam konteks Islam yang tengah mendominasi perdagangan di kawasan Asia Tengah dan Timur Tengah.

Alur perdagangan yang kompleks dan global banyak mempengaruhi corak perkembangan Islam di Nusantara, khususnya di Sumatera dan Jawa. Pengaruh Hindu-Budism, Pagan India dan Asia Tenggara bagian utara telah menjadikan Islam yang berkembang di Nusantara tidaklah berakar pada Islam yang berkembang di Makkah.

Pada periode berikutnya perkembangan mistisisme pun semakin kuat, demikian pula dengan semakin besarnya hasrat untuk menaklukkan Cina dan Syiria. Tradisi mistisisme tersebut kemudia semakin berkembang hingga ajaran Islam dan Hindu menjadi suatu sintesa, yaitu ajaran yang meletakkan Allah sama dengan Rama. Perkembangan mistisisme yang bergerak sampai tahun 1800-an ditandai dengan beberapa peninggalan yang berbau sinkretik seperti Tajmahal. Tradisi inilah yang kemudian berkembang menjadi sufisme yang juga telah berkembang di Arab terutama di Pesia dan sekaligus mempengaruhi sufisme di India yang bias di tandai dengan tokoh seperti Jalaluddid Ar-Rumi.

Pentingnya India bagi Aceh tampak pada masa kehadiran tokoh sufi yang datang ke Aceh pada tanggal 31 Mei 1637, yaitu Syekh Nuruddin Muhammad Ibnu Ali Hamid Ar-Raniri.Tokoh tersebut adalah yang mengarang buku Bustanus-Salatin yang dilakukan pada masa Sultan Iskandar Tsani, sebagai karya yang cenderung merupakan ensiklopedi yang di dalamnya terdapat salah satu bagian cerita tentang sejarah Islam pada masa raja-raja Delhi.

Dalam proses Islamisasi di Aceh tampaknya diwarnai dengan konflik yang cukup keras yang tidak hanya berlangsung pada masa Ar-Raniri saja. Fase kekerasan tersebut ditandai corak politik Ala-addin, dan formasi tersebut tentunya telah belangsung ratusan tahun (jika dihitung dari awal masuknya Islam yang diperkirakan pada abad ke-12. 
Dalam catatan Marcopolo yang pernah datang ke Perlak pada tahun 1292 M menyebutkan, para pedagang melakukan pengislaman kepada penduduk setempat dengan jalan damai dan banyak berlangsung melalui perkawinan, baik yang bersifat politis maupun yang non politis. Sementara itu dari catatan Ibnu Batutah yang sempat berkunjung ke Pasai menyebutkan bahwa kerajaan ini berakhir pada tahun 1521dan kemudian diduduki oleh Portugis selama tiga tahun. Dan pada tahun 1345-1346 (pada masa kekuasaan AlMalik Az-zahir disebutkan adanya perang melawan orang-orang yang dianggap kafir (orang-orang Batak yang belum Islam).

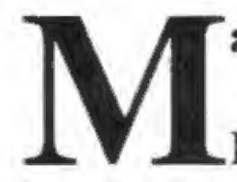

\section{asuknya Islam ke Kerajaan-Kerajaan}

- A wal Perkembangan Islam di Sumatera

Lamuri dan beberpa kerajaan lain yang ada di Sumatera Utara merupakan kerajaan yang beragama Budha. Mereka memiliki hubungan yang erat sekali dengan Cina baik dalam hubungan perdagangan maupun politik. Kerajan Lamuri tampaknya merupakan sebuah kerajan besar yang tidak hancur begitu saja karena serangan Rajendra Cola I pada abad ke-10, Bahkan dari Hikayat Raja-Raja Pasai menunjukkan bahwa Lamuri masih berdiri sampai di abad 15 .

Disebutkan juga bahwa proses Islamisasi di Sumatera Utara dilakukan oleh Nahkoda yang berasal dari Makkah, yaitu Syekh Ismail. Rombomgan tersebut singgah di Barus, sebagai tempat yang paling banyak koloni Arab, kemudian mengenai istilah mengislamkan penduduk dapat ditafsirkan sebagai menggalang kekuatan koloni yang telah kawin-mawin semenjak abad ke-7 $\mathrm{M}$.

Proses Islamisasi di tengah masyarakah lokal yang masih memeluk agama Hindu dan Budha dapat berlangsung secara cepat, dan hal tersebut merupakan hal yang sangat luar biasa. Jika benar proses tersebut berjalan cepat, maka kernungkinan yang paling kuat adalah kerajaan -kerajaan di Sumatera tersebut telah memiliki masyarakat yang plural sehingga ikatan di dalamnya cukup lemah. Sementara itu Kerajaan Pasai yang posisi politisnya lebih lemah daripada Lamuri tampaknya memilih Islam sebagai kepentingan politik dan selanjutnya baru menggeser posisi Lamuri, yaitu setelah Pasai menggabungkan diri dengan Kerajaan Samudera.

Kemudian mengenai masuknya Islam di daerah Minangkabau (Sumatera Barat) berlangsung ketika pusat kekuasaan dan keagaman lama telah mengendurkan kendalinya atas masyarakat, meskipun warisan lama terdapat di mana-mana. Alam Minangkabau tidak identik dengan dengan negara sebagaimana orang Minangkabau melihatnya. Sejarah kerajan Minangkabau sepeninggal Adityawarman hingga akhir abad ke-18 M, menunjukkan raja lebih merupakan simbol daripada manifestasi sesungguhnya kekuasaan kerajaan atas Alam Minangkabau (Dobbin I983). 
Daerah yang kini dikenal dengan Minangkabau bukanlah merupakan pemukiman baru, tetapi telah memiliki tradisi dan kehidupan sosial politik dan ekonominya dalam waktu yang lama, yaitu sebelum Islam merambah alam Minangkabau, daerah ini juga telah menerima kedatangan agama Hindu-Jawa beraliran Tantrayana, dengan Adityawarman (1347-1375) sebagai rajanya yang termasyhur. Kebanyakan petani Minangkabau sejak pra-Islam sampai abad ke-19 M masih menganut Animisme, dengan keyakinan bahwa dunia ini didiami oleh Roh. Jika terdapat keyakinan yang lain unsur animismenya masih sangat terasa.

Relasi Islam dengan nilai dan tatanan lama tersebut menunjukkan adanya pertemuanpertemuan yang tidak mudah dan tidak pula sederhana . Gelombang Islamisasi di Minangkabau dari modus jalur dagang, tarekat, orientasi fikih yang lebih kuat dan ortodok, gerakan salaf yang mengajak kembali ke sumber-sumber Islam awal, bahkan hingga gerakan modern Islam dan pergolakan dengan komunis pada abad ke-20, kesemuanya menampilkan corak hubungan Islam dengan formasi sosial.

Ulakan telah tercartat sebagai pusat keagamaan Islam tertua di Minangkabau dengan tokoh utama Syekh Burhanuddin yang pernah berguru kepada Syekh Abdul-Rauf Singkel di Aceh. Beliau terkenal sebagai ulama terpandang yang mendirikan pusat keagamaan di Ulakan tersebut. Kesan sebagai salah satu pusat modernisme Islam tampak muncuk sejak tarekat tidak banyak disebut-sebut sampai menjelang kemerdekaan, dan banyak tokoh nasional yang berasal dari Minangkabau seperti; Hamka Yamin, Hatta dan Syahrir tetapi mereka tidak menunjuk adanya keterkaitan dengan tarekat.

Islamisasi di Minangkabau, selain dari pantai Barat juga terjadi melalui sungaisungai yang bermuara di pantai timur. Sultan Mansyur Syah dari Malaka yang meninggal pada tahun 1475 telah tercatat sebagai tokoh yang pernah berkuasa di daerah Kampar dan Inderagiri. Demikian pula daerah Buo Sumpur Kudus, tempat keluarga Raja Minangkabau berpidah dan melakukan perdagangan emas dengan selat Malaka yang diislamkan sejak abad ke-15 adalah merupakan Islamisasi dari pantai timur.

Dalam kasus gerakan Paderi awal yang jelas telah dipengaruhi oleh kaum Wahabi di Saudi Arabia, akan tampak bahwa Islam telah berhasil membangun struktur sosial, politik dan kultural yang signifikan. Akan tetapi bagaimanapun, sinkritismenya tidak dapat dihindarkan dari Islam (dalam hal ini Tarekat Syattariyah dan Naqsyabandiyah) menyesuaikan dengan institusi pendidikan lama dan mengembangkannya menjadi surau-surau dalam arti pesantren. Islamisasi di Minangkabau membuktikan, bahwa penyebaran Islam di Minangkabau bermula dari daerah-daerah pantai dan mendapatkan penerimaan yang baik.

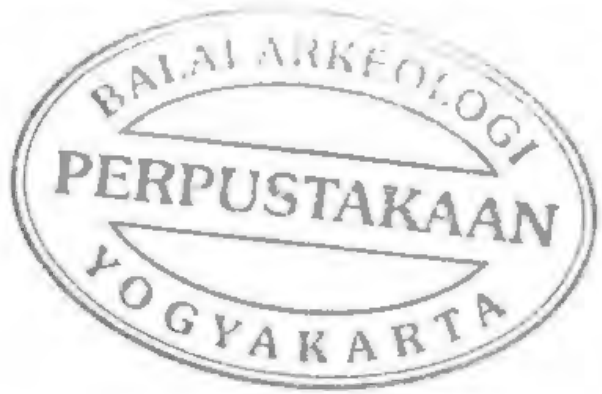


Ketika perdagangan komoditi pertanian meluas dan kesejahteraan meningkat, giliran aktivisme Syattariyah dan gerakan Paderi awal memainkan peran dalam penguatan Islam di Minangkabau hingga awal abad ke-19 M. Surau-surau (pesantren) yang telah berhasil menyesuaikan diri dan mendapat penerimaan luas dalam kehidupan petani minangkabau dan telah memainkan peran penting, terutama di daerah segitiga Agam.

Namun perlu juga di ketahui bahwa perselisihan terjadi di kalangan umat Islam sendiri, yaitu ketika warna baru dengan elemen Wahabi memasuki wilayah tersebut. Gelombang ini dimungkinkan antara lain; karena kelancaran arus perdagangaan dan transportasi ke Timur Tengah. Kemakmuran masyarakat yang meningkat dan meningkatnya kesadaran penduduk untuk menunaikan ibadah haji pada tahun 1803 M, yang diprakarsai tiga orang tokoh ,yaitu Haji Miskin dari Batu Tebal, Haji Sumanik dari tujuh koto dan Haji Piobang dari Lima Puluh Koto.

Atas saran Haji Miskin "administrasi Padri" bergaya Wahabi supaya dibangun di daerah Bukit Komang. Kerja sama tokoh-tokoh Padri ini telah membawa Islam semakin berpengaruh secara sosial, politik dan militer, dan kegiatan tersebut berlanjut hingga di tempat-tempat lain mendekati pantai Timur Minangkabau. Di sisi lain, tarekat Naqsyabandiyah telah diperkenalkan sebagai pembaharuan Islam di bawah pimpinan Tuanku Nan Tuo di Koto dengan muridnya terkemuka bernama Syekh Jalaluddin, sehingga dikenal sebagai pusat "Islam Cangking" yang berbeda dengan Islam Ulakan.

Perlu juga dikemukakan bahwa Minangkabau pasca Imam Bonjol adalah wilayah yang mengalami eksploitasi ekonomi dan penindasan politik Belanda yang intensif, yaitu dengan sistem Tanam Paksa pada tahun 1847-1908. Pada tahun 1870 sistem tersebut mendatangkan keuntungan yang tinggi bagi Belanda, namun hal tersebut telah dijalankan dengan paksaan bahkan pada tahun 1849 pernah terjadi kekrasan. Kemudian pada satu dasa-warsa berikutnya sistem tersebut mulai gagal memenuhi keinginan Belanda. Dan di tengah-tengah situasi demikian, Tarekat Naqsyabandiyah memainkan peran Islamisasi di Minangkabau, terutama sesudah tahu 1850-an.

\section{- Awal Perkembangan Islam di Jawa}

Islam masuk ke Nusantara secara sistematis sejak abad ke-14 Masehi, berpapasan dengan suatu kebudayaan besar yang telah menciptakan suatu sistem politik, nilajnilai estetika, dan kehidupan sosial keagamaan yang sangat maju yang dikembangkan oleh kerajaan-kerajaan Hindu-Budha di Jawa (Geertz, 1968).

Hadirnya Islam pertama kali di Jawa hingga sekarang belum diketahui secara pasti. Namun demikian, bukti arkeologis berupa nisan dengan muatan inskripsinya yang terdapat di kompleks makan Leran Gresik dengan tokoh yang dimakamkan "Fatimah 
binti Maimun bin Hibbatallah" serta angka tahun $495 \mathrm{H}(1082 \mathrm{M})$ telah menjelaskan bahwa bukti tersebut merupakan bukti tertua di Jawa, bahkan tertua di Asia Tenggara Hal tersebut menunjukkan bahwa pada akhir abad 11 Masehi Islam telah datang di Jawa. Sejak akhir abad -11 hingga abad -13 Masehi, bukti kepurbakalaan tentang datangnya Islam di Jawa sangat sedikit. Akan tetapi mulai akhir abad 13 Masehi, terutama ketika Kerajaan Majapahit mencapai puncak kebesarannya, proses sosialisasi Islam dapat diketahui lebih banyak. Hal ini didasarkan pada beberapa bukti nisan kubur di Gresik, Troloyo, dan Trowulan. Bahkan dalam berita Cina (Ma-Huan) tahun 1416 Masehi menceritakan bahwa di pusat Majapahit maupun di pesisir terutama di daerah kota pelabuhan telah terjadi proses sosialisasi Islam dan terbentuknya masyarakat muslim (Tjandrasasmita, 1975).

Pulau Jawa merupakan bentang lahan yang berada pada posisi yang sangat menguntungkan, yaitu posisi yang dapat membawa dampak akumulasi kultural dan politik yang datang dari berbagai arah. Hubungan yang terus-menerus antara pulau Jawa dengan pulau-pulau lain yang berakibat terjadinya akulturasi, yaitu menyerap tradisi dari berbagai negeri yang sering berkomunikasi dengan Pulau Jawa. Sejak datangnya Islam di Nusantara yang ditandai dengan berbagai tinggalan arkeologis, baik yang bersifat monumental maupun yang non monumental, diantaranya sebuah makam kuna (tertua) yang terdapat di Gresik, yaitu makam Fatimah Binti Maimun, dengan kronologi yang menunjuk angka tahun 1082/1102 $\mathrm{M}$, adalah suatu bukti adanya hubungan antara Jawa dengan negeri lain.

Awal-mula terjadinya proses sosialisasi Islam di Jawa adalah diprakarsai oleh orangorang alim dan ahli di bidang agama Islam (para wali), dan para ahli agama yang tergolong ulama. Mereka tidak hanya datang dan menetap di kota-kota tetapi juga masuk ke daerah-daerah pedalaman, sehingga pada akhirnya proses persebaran Islam berkembang tidak hanya di kota-kota tetapi juga di daerah-daerah pedalaman atau daerah pegunungan. Meskipun demikian, proses yang ditempuh oleh para tokoh penyebar Islam tersebut tidak mudah serta memakan waktu yang cukup panjang, dimana pada masa pemerintahan sultan-sultan Demak dan masa pemerintahan Sultan Agung Mataram yang secara aktif melancarkan proses sosialisasi Islam, penuh dengan tantangan dan harus dilakukan secara bertahap.

Pertumbuhan komunitas muslim di sekitar Majapahit, terutama di beberapa pelabuhan (di daerah pesisir utara Jawa) sangat erat hubungannya dengan perdagangan dan pelayaran yang dilakukan oleh orang-orang muslim dari manca negara yang telah memiliki kekuasaan ekonomi dan politik. Pada permulaan masuknya Islam di Jawa Timur terutama di daerah kekuasaan Majapahit (Hindu) mungkin belum dirasakan akibatnya di bidang politik oleh kerajaan Majapahit dan kedua belah pihak mungkin lebih mementingkan usaha untuk memperoleh keuntungan dagang, sehingga 
mengenai perbedaan agama tidaklah menjadi masalah dan pada akhirnya Islam dapat masuk di Jawa Timur secara damai atau tidak dengan kekerasan (Kempers, 1959 ).

Serangkaian batu nisan yang di temukan di Troloyo, Trowulan menunjukkan makam orang-orang muslim, meskipun lebih banyak menggunakan angka-angka tahun saka dan Jawa daripada angka-angka Arab (Hijriyah), namun dapat dipastikan bahwa makam-makam tersebut merupakan tempat penguburan orang-orang muslim Jawa, (Ricklefs, 1998).

Pada sekitar abad-14 Masehi, di Jawa telah memperlihatkan bukti kuatnya mengenai peranan masyarakat muslim, terutama di daerah pesisir utara. Hal ini terbukti dengan hadirnya makam-makam kuna di Troloyo yang berangka tahun 1290 Caka (1368/1369 M), dan sekaligus sebagai bukti kemungkinan adanya masyarakat muslim di dekat pusat kerajaan Majapahit. Kemudian sejak abad-15 dan permulaan abad-16 Masehi, di beberapa daerah pusat perdagangan, yakni di Gresik, Demak, Cirebon dan Banten telah menunjukkan adanya kegiatan keagamaan yang diprakarsai oleh para wali di Jawa. Sementara itu pada pertengahan abad-16 Masehi, Demak yang pada waktu itu sebagai penguasa Islam di Jawa telah menaklukkan majapahit, dan kemudian sejak itulah perkembangan Islam di Jawa dapat berperan secara politis, yaitu para wali dan tokoh-tokoh penyebar Islam telah dibantu oleh Demak dan kemudian Mataram dapat mensosialisasikan Islam, tidak saja di daerah-daerah penting di Jawa, tetapi tetapi juga daerah-daerah di pedalaman atau pegunungan di Jawa, termasuk daerah-daerah Jawa bagian selatan.

Kemudian mengenai perkembangan Islam di Jawa, pada sekitar abad-15 Masehi yang bermula di sepanjang pesisir utara yang pada waktu itu berperan sebagai jalur lalulintas internasinal dan sekaligus sebagai pusat penyebaran Islam yang dalam perkembangannya diprakarsai oleh para tokoh penyebar Islam (para wali) yang dalam operasionalnya tidak hanya menetap di kota, tetapi juga masuk ke daerah-daerah pedalaman. Disamping itu, mereka juga didukung dengan potensi kemampuan dalam hal keagamaan maupun strategi pengembangannya. Baru kemudian pada abad -16 Masehi Islam dapat berkembang di beberapa daerah di pedalaman Jawa (Jawa bagian selatan) yang diprakarsai oleh tokoh kharismatik, yaitu Sunan Pandanaran (Sunan Tembayat) yang dianggap oleh Graaf tidak termasuk Walisongo yang memiliki peran penting dalam penyebaran Islam di Jawa (Graaf, 1985)

Kemudian pada sekitar abad-17 - 18 Masehi, di Jawa telah terjadi pergulatan antara para penyebar Islam; pedagang, musafir dan ulama dan kaum sufi yang dampaknya semakin diakuinya peranan mereka dalam struktur komunitas pribumi, sehingga para tokoh tersebut dapat menduduki jabatan dalam struktur birokrasi kerajaan. Hal ini tentunya tidak terlepas dari strategi dakwah Islam yang dilakukan oleh para tokoh penyebar Islam tersebut, sehingga mereka dapat melakukan dakwah secara langsung 
kepada raja dan keluarganya, mendirikan masjid, mendidik kader ulama, serta pendekatan-pendekatan sosial yang sesuai dengan kondisi masyarakat setempat, (Ambary, 1998).

Setelah Kerajaan Majapahit runtuh, pusat kekuasaan beralih ke Jawa Tengah (Demak), dengan raja pertamanya Raden Patah. Meskipun demikian bukan berarti bahwa pengembangan Islam di Jawa Timur terhenti sama sekali. Tetapi justru sejak saat itu proses sosialisasi Islam di Jawa Timur semakin meluas, karena di sisi lain di daerah jawa Timur, menurut berita dari Tom Pirees masih terdapat beberapa kerajaan kecil yang belum Islam, seperti Pasuruhan, Panarukan, dan Blambangan. Hal itu dilakukan dengan kerjasama antara pusat-pusat pesantren yang juga semakin berkembang, seperti di (Surabaya, Gresik dan Tuban) dengan pusat kerajaan Islam di Demak Jawa Tengah.

\section{- Aliran-Aliran Mistisisme dalam Islamisasi}

Dalam penyebaran Islam di beberapa bagian kawasan Nusantara, kaum sufi mempunyai peranan penting. Pada tahun 1961 A.H. John berpendapat bahwa kaum sufi dan sufismenya mempunyai peranan penting dalam penyebaran Islam yang didasarkan pada sumber-sumber tertulis berupa babad dan hikayat di Jawa dan Melayu, seperti Babad tanah Jawi, Sejarah Banten, Hikayat Raja-Raja Pasai, Sejarah Melayu dan lain sebagainya.

Kaum sufi adalah kaum atau sebagian kelompok dalam masyarakat Islam. Menurut Harun Nasution; Aliran sufisme itu dimungkinkan muncul dari pengaruh Kristen, filsafat mistik Phytagoras, falsafah emanasi Plotinus, Budha, maupun Hindu. Tetapi bagaimanapun dengan ada atau tanpa pengaruh dari luar, sufisme bisa timbul dalam Islam. Hal ini didasarkan beberapa ayat al-Qur' an antara lain, Surat al -Baqarah 115 dan 186, surat Qaaf ayat 16, surat al-Anfal ayat 17, surat Ali Imran Ayat 185 Surat al-Ankabut ayat 57, surat Arrahman ayat 26 dan 27. serta beberapa hadits yang menyatakan bahwa manusia dengan Tuhan adalah satu sehingga untuk mengetahuinya tidaklah perlu pergi jauh-jauh, cukuplah dengan ia masuk ke dalam dirinya dan mencoba mengetahui dirinya, (Nasution, 1981).

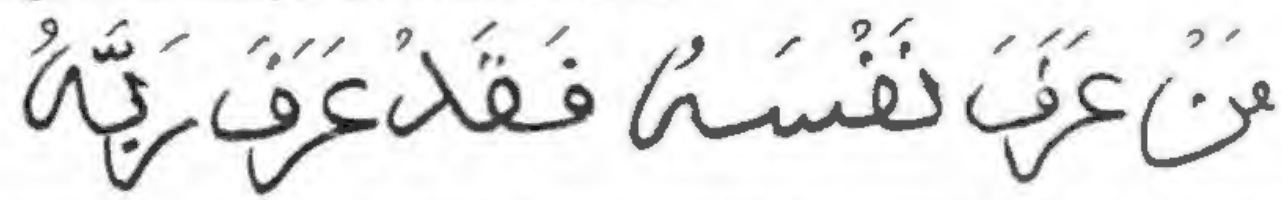

Barang siapa yang mengetahui dirinya, maka sungguh ia akan mengetahui Tuhannya

Kelompok masyarakat muslim mulai menjalankan pertapa atau ascetik sejak abad ke8 dan ke-9 $\mathbf{M}$ sampai berkembangnya tasawwuf di daerah Persi dan Irak pada sekitar abad -12 dan 13 Masehi dan kemudian mulai tersebar ke seluruh dunia Islam. 
Dengan munculnya seorang tokoh sufi Al-Ghazali dengan ajaran-ajaran tasawwufnya, maka sufisme tetap berada dalam dunia Islam, karena Al-Ghazali membawa ajaran tasawwufnya kembali berpedoman kepada al-Qur'an dan AsSunnah. Beliau terkenal sebagai Hujjatul-Islam yang dapat dilihat melalui sejumlah karyanya yang cukup banyak, diantaranya adalah Ihya' 'Ulumuddin sebagai salah satu karya yang mendapat kedudukan yang istimewa, karena kupasannya yang populer dan sistematis yang mencakup permasalahan-permasalahan ibadah, etika, kejahatan dan pujaan, (Masyhudi, 2001).

Sejak abad-13 Masehi kaum sufi menyebar ke berbagai negeri diantaranya ke Indian dan beberapa negara di Asia Tenggara. Di Nusantara, refleksi ajaran-ajaran tasawwuf dan perkembangannya baru muncul pada abad 16 dan 17 Masehi, terutama di Sumatera dan Jawa, dan mulai saat itulah mulai dikenal ahli-ahli tasawwuf, seperti Hamzah Fansuri, Syamsuddin As-Sumatrani, Nuruddin ar-Raniri, Abdul-Rauf Singkel, dan beberpa tokoh di Jawa diantara Walisanga seperti; Syekh Siti Jenar, atau Syekh Lemah abang, Sunan Bonang, dan Sunan Panggung yang juga terkenal telah mengajarkan tasawwuf atau ilmu suluk.

Di Indonesia terdapat dua macam aliran tasawwuf (mistisisme), yaitu Heterorthodox dan orthodox. Aliran Heterorthodox dikenal juga dengan istilah aliran Wujudiah yang berpandangan bahwa wujud makhluk-makhluk Allah sebenamya tidak ada, tetapi yang ada hanyalah ciptaan-Nya. Dalam aliran ini juga terdapat ajaran yang dikenal dengan istilah yang lebih popular yaitu Martabat Tujuh, yaitu ajaran tentang emanasi yang sangat erat dengan ajaran Ibnul-'Arabi.

Aliran Wujudiah adalah bersifat pantheistis-monistis sebagaimana ajaran-ajaran Siwa dan Budha Mahayana. Sehingga persamaan persamaan itulah yang mungkin menyebabkan agama Islam melalui ajaran tasawwuf lebih diterima oleh masyarakat Indonesia, baik di Sumatera maupun Jawa.

Dalam ajaran martabat tujuh disebutkan bahwa segala yang ada di alam semesta ini adalah aspek lahir dari suatu hakekat yang tunggal (Tuhan). Tuhan sebagai dzat yang mutlak tidak dapat dikenal oleh indera, akal dam khayal, Dia hanya dapat dikenal dengan cara bertajalli (menampakkan diri keluar sebanyak tujuh martabat. Tiga tajalli yang pertama adalah martabat ahadiyah (kesatuan mutlak) martabat wahdah (kesatuan yang mengandung kejamakan secara global), danmartabat wahidiyah (Kesatuan dalam kejamakan secara rinci). Dari ketiga martabat tersebut muncullah aspek lahir, yaitu alam arwah, alam mitsal (kesatuan dalam kejamakan secara global) dan alm ajsam atau alam segfala tubuh (kesatuan dalam kejamakan secara rinci). Dari ketiga martabat lahir dan martabat batin terkumpul dalam martabat yang ke tujuh, yaitu alam insan, (Simuh, 1988). 
Pada masa pemerintahan Sultan Al-Malik Az-Zahir (cucu Sultan Al-Malik Al-Saleh) Ibnu Batutah pernah mengunjungi Sunmatera, yaitu pada tahun 1345 Masehi. Diceritakan bahwa Sultan Samudera amat menyukai agama yang dibuktikan dengan diskusi-diskusi theology dan mistik-mistik Islam (Tasawwuf). Dengan adanya aktivitas tersebut, hubungan Pasai dan Malaka pada abad-14 dansampai puncaknya pada abad !5, Malaka menjadi pusat diskusi keagamaan yang memungkinkan terlibatnya ahli-ahli Tasawwuf.

Jika para ahli tasawwuf tersebut benar pernah berkumpul di pusat-pusat kerajaan, maka refleksinya di bidang lain kemungkinan sudah ada. Refleksi dimaksud adalah unsur-unsur tasawwuf sebagaimana terdapat pada nisan kubur Sultan Almalik-AlSaleh;

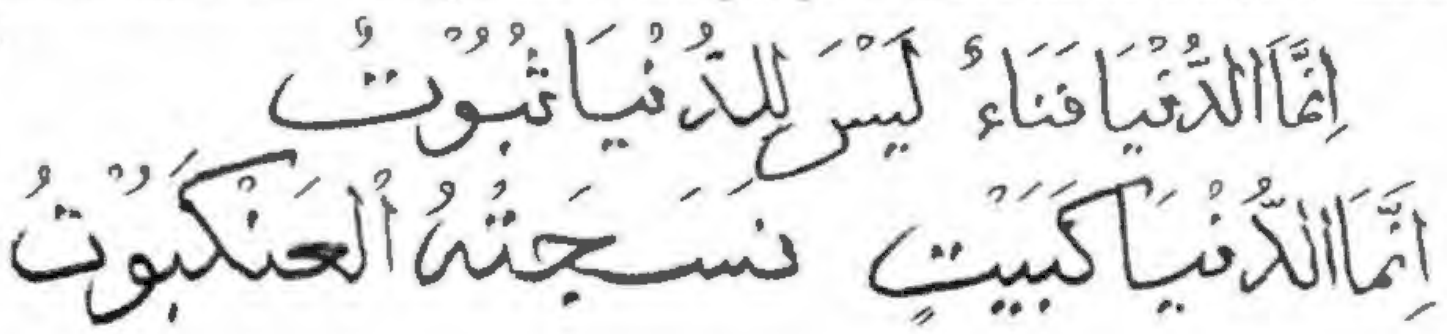

Sesungguhnya dunia ini fana, tiadalah dunia ini akan kekal

Sesungguhnya dunia ini bagaikan jaring-jaring yang disusun oleh laba-laba

Pada nisan kubur Raja Fatima dan Raja Jamil juga terdapat inskripsi ;

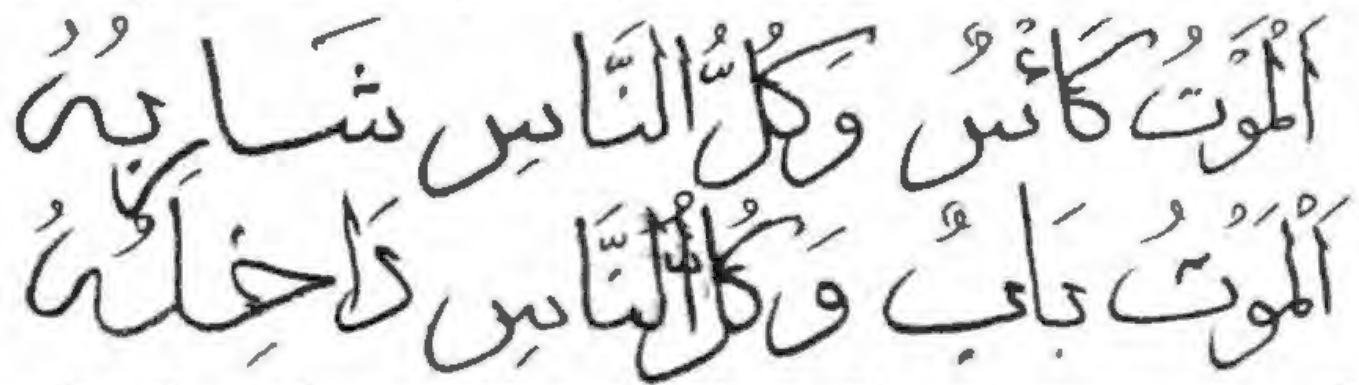

Kematian bagaikan minuman dalam sebuah cangkir yang semua orang akan meminumnya.

Kematian bagaikan sebuah pintu yang semua orang akan memasukinya.

Dalam aliran Wujudiah yang diajarkan oleh Hamzaf Fansuri terdapat suatu doktrin tentang Ana al-Haq sebagaimana doktrin yang pernah diajarkan oleh Al- Hallaj di Persia. Doktrin tersebut ditentang oleh Nuruddin Arraniri dalam kitabnya Asrarulinsan fi makrifatir-ruh war-Rahman. Siapa yang mengenal dirinya sebagai makhluk, maka ia akan mengenal Tuhan sebagai pencipta. Siapa yang mengenal dirinya sebagai makhluk yang fana maka ia akan mengenal Tuhan sebagai yang baqa.

Di Jawa, sebagaimana ajaran yang menyerupai ajaran wujudiah dari Syekh Siti Jenar telah ditentang oleh Sunan Bonang dalam Buku Bonang. Dalam ajaran Sunan Bonang 
yang termuat dalam primbon abad-16 tersebut ditujukan untuk menentang faham Kawula Gusti atau Ana al-Haq-nya Syekh Siti Jenar

Mistisisme (tasawwuf) senantiasa berhubungan erat dengan Tarekat, yaitu jalan yang ditempuh oleh kaum sufi dalam rangka pendekatan dirinya kepada Tuhan. Di Indonesia terdapat tarekat-tarekat yang mempunyai pengaruh terhadap umat Islam, diantaranya, Qadiriyah, Naqsyabandiyah, Sammaniyah, Qusyaisiyah, Syatariyah, Syadziliyah, Khalwa'iyah dan Tijaniyah.

Sebagaimana kita ketahui bahwa awal kedatangan Islam dan penmyebarannya bukan saja dilakukan oleh kaum sufi, mungkin juga para pedagang muslim ataupun para muballigh. Akan tetapi jika dihubungkan dengan terjadinya penyebaran kaum Sufi di Persia dan Irak keluar daerah sejak abad ke-13 Masehi, maka tidak mustahil kaum sufi juga memasuki beberapa daerah di Asia Tenggara, termasuk Sumatera dan Jawa. Suksesnya proses Islamisasi di Sumatera dan Jawa secara jelas banyak menentukan sikap budaya dari masyarakatnya. Artinya Islam telah menjadi suatu energi yang luar biasa dalam membentuk karakter budaya masyarakatnya.

Tokoh-tokoh yang berpengaruh pada masa Sultan Iskandar Muda adalah Hamzah Fansyuri dan Syamsuddin Sumaterani. Mereka adalah tokoh mistik yang sangat berpengaruh pada perkembangan ajaran Panteisme di kawasan Aceh. Kedua tokoh tersebut telah mengembangkan ajaran wujudiyah (wahdatul-wujud), merupakan aliran dalam tasawwuf yang berarti jalan atau tuntunan yang menekankan ajaran-ajaran untuk melakukan asketisme. Ajaran ini merupakan ajaran para sufi yang banyak berkembang di Persia yang menekankan "kalam dan Allah adalah satu", yang berbeda dengan pandangan ahli ilmu kalam yang membedakan wujud menjadi dua, yaitu wajibul-wujud (yang bersifat abadi) dan mumkinul-wujud (yang bersifat fana).

Hamzah Fansyuri yang terkenal dengan karya- karya sastra sufinya cenderung mengikuti ajaran Ibnu Arabi dan juga dipengaruhi oleh Abdul-Karim al -Jili serta pemikiran Al-Hallaj, Al-Bistmi, Al-Bangdady, Al-Ghazali, Mas'udi, Attar, Jalaluddin Ar-Rumi, Iraqi, Sa'di, Syabistari, Maghribi dan Syekh Nikmatullah,

Kemudian untuk daerah Minangkabau (Sumatera Barat), tokoh penting Tarekat Naqsyabandiyah adalah Syekh Ismail Simabur (Batu Sangkar) yang bermukim di Makkah. Sedangkan Syekh pertama dan paling berpengaruh dari Tarekat Naqsyabandiyah di Minagkabau adalah Syekh Jalaluddin dari Cangking. Daya pikat tarekat Naqsyabandiyah ini begitu kuat, sehingga banyak orang yang berminat untuk mengikuti tarekat Naqsyabandiyah. Dan Tarekat ini lebih berorientasi ke Makkah, dan meninggalkan orientasi lokal. 


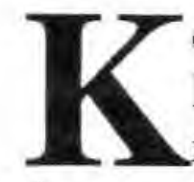

esimpulan

Hubungan dagang antara orang Eropa dengan Timur Tengah yang telah mewarnai peta dagang sebelum masa Islam menunjukkan bahwa hubungan dagang antara Eropa dengan Asia telah berlangsung semenjak sebelum nabi Isa a.s. Kemudian setelah runtuhnya dominasi India dan Cina, karena ditaklukkannya India bagian utara yang kemudian merembet ke Selatan dan penyerangan ke China oleh tentara Islam di Timur Tengah, maka tampaklah gelombang orang-orang Arab mulai membentuk koloni-koloni bagi para pedagang. Hubungan dagang dan politik antara Cina dengan Persia, Cina dengan Sriwijaya, India dengan Sriwijaya dan India dengan Cina merupakan hubungan yang telah berlangsung selama berabad-abad. Hubungan semacam ini tidak mungkin terhapus begitu saja. Oleh karena itu ketika ajaran Muhammad (Islam) mulai mapan di Timur Tengah dan berkuasa di India bagian utara, maka arus perdagangan internasional semakin diintensifkan, demikian pula ajaran Islam itu sendiri.

Corak perkembangan Islam di Nusantara banyak dipengaruhi oleh alur perdagangan yang global. Pengaruh Hindu-Budism, Pagan India dan Asia Tenggara bagian utara telah menjadikan Islam yang berkembang di Indonesia tidaklah berakar pada Islam yang berkembang di Makkah, bahkan sinkretisme yang kental dan pengaruh ajaran mistik dari Persia pada saat itu telah mewujudkan corak Islam di Nusantara. Meskipun Islam telah merambah ke Nusantarapada abat ke-7 Masehi, pengaruh Islam di Sumatera pada waktu itu belum begitu berarti. Islamisasi belum berlangsung secara intensif karena masih kuatnya dominasi Cina dan India. Hinduisme dan Budhisme menjadi instrumen agama yang mengatur tata kehidupan masyarakat yang memiliki hubungan politik dengan India dan Cina.

Kerajan Pasai yang dirajai oleh Sultan al-Malikus-Saleh merupakan negara yang mengandalkan perdagangan sebagai basis ekonomi negara, terutama dapat dilihat dari letak yang dekat dengan pantai. Dan menguatnya kerajan Islam merupakan unsur utama dalam menuju hegemonisasi ideologi sehingga proses islamisasi pun berlangsung. Para pedagang Gujarat yang memanfaat kan Islam telah menjadi pengekspor batu nisan yang digunakan oleh para penguasa Islam di Sumetera Utara dan Jawa. Batu nisan dari Cambay tampak telah menjadi Simbol yang prestisius bagi sultan-sultan yang meninggal dan juga untuk melegitimasikan kerajaan tersebut di dalam konteks Islam yang tengah mendominasi perdagangan di kawasan Asia Tengah dan Timur Tengah.

Kemudian pada periode berikutnya perkembangan mistisisme pun semakin kuat, demikian pula dengan semakin besarnya hasrat untuk menaklukkan Cina dan Syiria. Tradisi mistisisme tersebut kemudian semakin berkembang hingga ajaran Islam dan Hindu menjadi suatu sintesa ajaran yang meletakkan Allah sama dengan Rama. 
Bukti arkeologis berupa nisan dengan muatan inskripsinya yang terdapat di kompleks makan Leran Gresik merupakan bukti tertua di Jawa, bahkan tertua di Asia Tenggara. Hal tersebut menunjukkan bahwa pada akhir abad 11 Masehi Islam telah datang di Jawa. Kemudia berdasarkan pada beberapa bukti nisan kubur di Gresik, Troloyo, dan Trowulan, bahkan dalam berita Cina (Ma-Huan) tahun 1416 Masehi menceritakan bahwa di pusat Majapahit maupun di pesisir terutama di daerah kota pelabuhan telah terjadi proses sosialisasi Islam dan terbentuknya masyarakat muslim (Tjandrasasmita, 1975).

Setelah Kerajaan Majapahit runtuh, pusat kekuasaan beralih ke Jawa Tengah (Demak), dengan raja pertamanya Raden Patah. Meskipun demikian bukan berarti bahwa pengembangan Islam di Jawa Timur terhenti sama sekali. Tetapi justru sejak saat itu proses sosialisasi Islam di Jawa Timur semakin meluas, karena di sisi lain di daerah jawa Timur, menurut berita dari Tom Pirees masih terdapat beberapa kerajaan kecil yang belum Islam, seperti Pasuruhan, Panarukan, dan Blambangan. Hal itu dilakukan dengan kerjasama antara pusat-pusat pesantren yang juga semakin berkembang, seperti di (Surabaya, Gresik dan Tuban) dengan pusat kerajaan Islam di Demak Jawa Tengah.

Kemudian mengenai perkembangan Islam di Jawa, pada sekitar abad-15 Masehi yang bermula di sepanjang pesisir utara yang pada waktu itu berperan sebagai jalur lalulintas internasinal dan sekaligus sebagai pusat penyebaran Islam, dalam perkembangannya diprakarsai oleh para tokoh penyebar Islam (para wali) yang dalam operasionalnya tidak hanya menetap di kota, tetapi juga masuk ke daerah-daerah pedalaman. Selain itu, mereka juga didukung dengan potensi kemampuan dalam hal keagamaan maupun strategi pengembangannya. Dan pada periode berikutnya, yaitu sekitar abad-16 Masehi Islam dapat berkembang di beberapa daerah di pedalaman Jawa (Jawa bagian selatan) yang diprakarsai oleh tokoh kharismatik, yaitu Sunan Pandanaran (Sunan Tembayat) yang dianggap oleh Graaf tidak termasuk Walisongo yang memiliki peran penting dalam penyebaran Islam di Jawa (Graaf, 1985).

Aliran Heterothdox, sebagai aliran yang bersifat Pantheistis-monistis memiliki jaran yang mirip dengan jaran-ajaran Siwa dan Budha Mahayana. Dalam aliran ini terdapat ajaran yang dikenal dengan istilah Martabat Tujuh, yaitu ajaran tentang emanasi yang sangat erat dengan ajaran Ibnul-'Arabi. Sehingga persamaan persamaan itulah yang memungkinkan menjadi sebab diterimanya Islam melalui ajaran mistisismenya lebih diterima oleh masyarakat Nusantara, baik di Sumatera maupun Jawa.

Dalam aliran Wujudiah yang diajarkan oleh Hamzaf Fansuri terdapat suatu doktrin tentang Ana al-Haq sebagaimana doktrin yang pernah diajarkan oleh Al- Hallaj di Persia. Doktrin tersebut ditentang oleh Nuruddin Arraniri dalam kitabnya Asrarulinsan fi makrifatir-ruh war-Rahman. Siapa yang mengenal dirinya sebagai makhluk, 
maka ia akan mengenal Tuhan sebagai pencipta. Siapa yang mengenal dirinya sebagai makhluk yang fana maka ia akan mengenal Tuhan sebagai yang baqa. Sementara itu di Jawa, ajaran yang menyerupai ajaran wujudiah adalah aliran dari Syekh Siti Jenar yang kemudian ditentang oleh Sunan Bonang dalam Buku Bonang. Dalam ajaran Sunan Bonang yang termuat dalam primbon abad-16 tersebut ditujukan untuk menentang faham Kawula Gusti atau Ana al-Haq-nya Syekh Siti Jenar

Dari uraian tersebut di atas nampak semakin jelas, bahwa dalam perkembangan Islam secara umum, baik di Sumatera maupun di Jawa, perdagangan merupakan suatu setrategi yang dominan diterapkan oleh para tokoh penyebar Islam yang datang dari berbagai negara. Disamping itu mistisisme pun ikut mewarnai proses perkembanagan Islam di Sumatera dan Jawa yang ditandai dengan banyaknya aliran-aliran mistik (mistisisme) yang muncul bersamaan dengan proses perkembangan Islam di Nusantara, khususnya di Sumatera dan Jawa. 


\section{KEPUSTAKAAN}

Ambary, Hasan Muarif, 1998. Menemukan Peradaban, Arkeologi dan Islam di Indonesia, Pusat Penelitian Arkeologi Nasional, Jakarta.

De Graaf, H.J. DR. TH, G. TH. Pigeaut. 1985. Kerajaan Kerajaan Islam di Jawa, Peralihan Dari Majapahit ke Mataram, Grafiti Pers, Jakarta.

Dobbin.Cristine, 1983. Islamic Revivalism in a Changing Peasant Economy Central Sumatra, 1784 - 1847, Curzon Press, London.

Geertz, 1968. Islam Observer, New Haven and London. Yale University Press.

Kempers, A.J. Bernet, 1959. Anscient Indonesian Art, Amsterdam.

Masyhudi, nfn. (2001). Peranan Tasawwuf Dalam Sosialisasi Islam Di Indonesia. Berkala Arkeologi, 21 (1), 68-78. https://doi.org/10.30883/jba.v21 il .834

Nasution, Harun, 1981. Islam Ditinjau dari Berbagai Aspek I, UI Press, Jakarta.

Payne, Rober, 1987. The History of Islam, Dorset Press, New York.

Ricklefs, M.C., 1998. Sejarah Indonesia Modern, Gadjah Mada University Press, Yogyakarta.

Said, Muhammad, 1961. Aceh Sepanjang Abad. Medan.

Simuh, 1998. Mistik Islam Kejawen, UI Press, Jakarta.

Tjandrasasmita, Uka, 1975. Aspek-Aspek Arkeologi Indonesia, Pusat Penelitian arkeologi Indonesia, Jakarta. 